УДК 94:316.4.063.7(477) «1914/1915»

ВИЗДРИК В.С.

https://orcid.org/000-0001-5427-5825

https://doi.org/10.33577/2313-5603.32.2019.3-16

\title{
ІДЕОЛОГІЧНИЙ ВПЛИВ РОСІЇ НА УКРАЇНСЬКИЙ СОЦІУМ ГАЛИЧИНИ НАПЕРЕДОДНІ ТА ПОЧАТКОВОМУ ЕТАПІ ПЕРШОЇ СВІТОвої ВІЙнИ
}

Початок XX століття ознаменував використання ідеології як інструменту зовнішньої політики. Росія у Першу світову війну вступила під гаслом звільнення поневоленого слов'янства, прагнучи реалізувати свою довоснну стратегічну мету, розширити кордони імперії за рахунок Галичини, Буковини і Закарпаття.

Інструментом ідеологічної політики Російської імперії напередодні війни був панславізм, месіанська місія щодо слов'янських народів. Для експансії Росія також використовувала культурно-релігійний вплив та посилення через нього своєї політичної присутності в регіоні.

Для дискредитації українського національно-визвольного руху в Галичині напередодні війни російські урядові та політичні кола морально i, головне, матеріально підтримували москвофільство. Через москвофільські організації російський уряд мав можливість проводити не тільки антиукраїнську пропаганду серед галицьких українців, перетягуючи їх на свою сторону, але й антидержавну - 3 метою приєднання до Росії всіх українських етнографічних земель, що входили до складу Австро-Угорської монархії.

Ключові слова: Перша світова війна, Галичина, москвофільство, ідеологічний вплив, пропаганда.

Постановка проблеми та ї̈ актуальність. Минуло більше п’яти років, як Україна зазнала агресивного нападу з боку Російської Федерації. За останній час присутність Росії в інформаційному просторі України лише зросла і питання достовірності інформації, довіри до керівництва армії та держави, збереження згуртованості нашого суспільства, стають вкрай важливими. Тому як ніколи актуальними є вивчення історичного минулого та уроків Першої світової війни, з'ясування перепитій ідеологічної боротьби ворогуючих країн, ролі і місця українського питання в інформаційній війні.

Виздрик Віталій Степанович, доктор історичних наук, доцент, професор кафедри гуманітарних наук, Національна академія сухопутних військ імені гетьмана Петра Сагайдачного, м. Львів.

(С) Виздрик В. С., 2019 
Аналіз попередніх досліджень і публікаиій. Історіографічний аналіз засвідчив, що за наявності значної кількості наукових робіт у вітчизняній та зарубіжній літературі, зокрема перебігу військово-політичних подій, бойових операцій, міграційних процесів, пропаганди періоду Першої світової війни, у вітчизняній історіографії досі відсутні комплексні наукові дослідження, присвячені ідеологічній боротьбі (під час якої широко використовувалася українська тематика) між двома протиборчими силами Австро-Угорською та Російською імперіями напередодні та на початковому етапі Великої війни.

Серед праць українських фахівців особливої уваги заслуговують дослідження В. Пасічника, який розглядав ідеологічну складову російської імперської політики на межі XIX-XX ст. (2014); О. Мосієнка про пропаганду на Південно-Західному фронті в роки Першої світової війни (2017), О. Куцької про структури пропагандистських органів всіх воюючих держав, форми та засоби пропаганди (2014), А. Науменка про питання інформаційного забезпечення російських військ у 1916 р. (2013).

Мета та завдання дослідження. полягає в тому, щоб з'ясувати особливості ідеологічної політики Росії напередодні Великої війни, проаналізувати інформаційний вплив на населення Східної Галичини та встановити характерні риси й особливості їі пропаганди.

Виклад основного матеріалу дослідження. Напередодні війни між Росією та Австро-Угорщиною точилася боротьба за гегемонію у слов'янському світі. У зв'язку з цим загострилася напруженість навколо української проблеми. Посол М. Василько у 1909 р. двічі піднімав в Австрійському парламенті питання щодо «русофільських підступів» у Галичині та Буковині. Зазначимо, що цісар Франц Йосиф публічно підтримав лідера буковинських українців (Bihl, 1990:41).

У грудні 1909 р. міністр внутрішніх справ Австро-Угорщини Г. Герділь звернувся 3 вимогою до Галицького намісника розслідувати факти підтримки крайовою адміністрацією русофільської пропаганди. Це дало привід намісникові М. Бобжинському заявити у Галицькому сеймі, що «розвиток руської національності в нашому краї може відбутися тільки на підставі народної руської мови та іiі окремого національного почуття, тому адміністрація держави не може толерувати штучно імпортованих з Росії течій» (ЦДІАУК, ф. 442, on. 864, сnр. 279, с. 165).

Відповідно до розпорядження Міністерства внутрішніх справ Австро-Угорщини 31 грудня 1913 р. розпущено «Общество имени 
М. Качковского» та «Русские дружины», а 2 березня 1914 p. видано дозвіл на запровадження надзвичайного стану у Галичині, у даному випадку йшлося про фактичне припинення русофільської пропаганди (Уська, 2004: 153-180).

Лідер галицьких українців, посол К. Левицький, виступаючи 8 травня 1914 р. у віденському парламенті, наголошував: «Росія вже на нашій східній границі, пропаганда православ'я це підготовка російської національної ідеї як стадії до відізвання Галичини i Буковини від Австрії» (Левицький, 1936:736).

Австрійські урядові чинники на початку 1914 р., після польськоукраїнської угоди, дедалі більше приділяли увагу українській проблемі всередині держави. Вони усвідомлювали, що успіх у тривалому суперництві з Росією у зовнішній політиці значною мірою залежатиме від галицьких українців. Це підтверджував австроугорський консул у Варшаві, барон Л. Андріан, який підготував для уряду спеціальний меморандум - «Значення української проблеми Галичини для зовнішньої політики загалом». У ньому він підкреслював: «За значенням для нашої зовнішньої політики і для монархії український народ обіймає перше місце. Від нашого ставлення до нього залежатиме майбутній перебіг історії АвстроУгорщини» (Hornykiewicz, 1966:450).

Зрозуміло, що український національний рух у Галичині став небезпечним для Російської імперії. Практично все російське суспільство - від шовіністів до лібералів вбачало у ньому загрозу цілісності Росії. 3 наближенням війни український чинник набував все більшого значення.

На початку XX ст. Росія у своїй політиці щодо українських земель керувалася, насамперед, принципом імперського централізму та викорінення будь-яких проявів національного сепаратизму. Російський уряд вважав небезпечним розвиток українського руху в Галичині. Особливість Галичини з ії українськими школами, політичними партіями, національним представництвом у сеймі та парламенті як приклад, добре організаційно вивершеного українського політичного руху стала для Наддніпрянщини безсумнівним фактом.

Щодо проблем, які можуть виникнути у Російській імперії у зв'язку 3 подальшим розвитком українського руху, граф В. Бобринський писав: «Якщо «руський» дух буде цілком зломлено, і Східна Галичина, та Буковина будуть повністю українізовані, то тоді сила ворожого натиску буде спрямована на нашу Малоросію, і українська пропаганда в нас значно посилиться. Тому 
ясно, що захист «руської» справи на Дністрі і Сяні стане його захистом на Дніпрі i, працюючи в Галичині, ми працюємо для нашої національної самооборони, незалежно від питання державного возз'єднання з нами Червоної Русі» (Бахтурина, 2000: 264).

Цілком зрозуміло, що український рух у Наддніпрянщині пробудило галицьке українство, тому для Росії як держави Галичина стала вогнищем ворожого сепаратизму. «Росія скоро зрозуміла, зазначав польський дослідник українського питання Л. Васілевський, що як добре Галичина не буде влучена в російську державу та як довго не буде піддана одностайному режимові з Наддніпрянською Україною, так довго Росія не позбудеться українського руху в своїх кордонах (Wasilewski, 1934:146).

Тому для дезорганізації українського руху в Галичині напередодні війни російські урядові та політичні чинники морально i, головне, матеріально підтримували москвофільство, в основу якого лягла всеросійська національна ідея. Царський уряд здійснював інформаційно-пропагандистську роботу в містах та населених пунктах прикордонної Галичини, зокрема, забезпечував агітаційними матеріалами читальні під виглядом благодійності, які поширювались через москвофільські організації: товариство ім. М. Качковського, «Благодійне Товариство видання загальнокорисних і дешевих книг» та інші. Російський уряд мав можливість проводити не тільки антиукраїнську пропаганду серед галицьких українців, перетягуючи їх на свою сторону, але й антидержавну - 3 метою приєднання до Росії всіх українських етнографічних земель, що входили до складу Австро-Угорської монархії (Дело народных читален, 1914:1).

У російському суспільстві все більше утверджувалася думка про важливе значення Галичини для внутрішньої і, особливо, зовнішньої політики Росії. Зазначалося, що Галичина - «справжня «русская» прикарпатська фортеця, прикордонна твердиня, сторожовий полк Росії, який розчищає попереду грунт і закриває тил у нашому дусі для виконання великих завдань, на кінець - сильна опора православ'я» (Гумеикий, 1904:112).

Напередодні війни в російській Думі й поза нею від російських політиків все частіше лунали слова про «українську небезпеку» для Росії в Австрії та погрози в сторону останньої за так звану допомогу українському рухові. Згодом міністр закордонних справ Росії С. Сазонов, говорячи про причини війни, однією з головних назвав «українську ідею» (Томамівський, 1915:32). 
Відомий ідеолог російського шовінізму П. Струве точніше висловився щодо українського національного руху. «Перш за все, зазначав він, - Росія повинна возз'єднати і об'єднати з імперією всі частини «руського» народу. Звідси випливає історична неминучість приєднання до імперії «русской» Галичини. Таке приєднання неминуче, як це, на жаль, цілком ясно виявилося саме у зв'язку з цією війною, і для внутрішнього оздоровлення Росії, тому що австрійське буття малоросійського племені породило і живило у нас потворне так зване «українське питання» (Струве, 1914:176-180).

Російська імперія напередодні Великої війни позиціонувала себе на міжнародній арені, як месія щодо слов'янських народів Балканського півострова, Австро-Угорської та Німецької імперій, проповідуючи ідеї панславізму. Царизм пропагував єдність всіх слов'ян на чолі з Росією перед натиском «войовничого германізму». Влада хотіла розширення Російської імперії за рахунок приєднання деяких територій Австро-Угорщини, аргументуючи це відновленням історичної справедливості, як правонаступниці Київської та Галицько-Волинської Русі. А місцеве населення Галичини і Буковини трактувалося як російське, відокремлене від єдиного російського народу історичними обставинами. «Таке єдине територіальне приєднання, - зазначав П. Мілюков, - яке малося на увазі на самому початку війни і яке безпосередньо випливало 3 загальних основ визволення і об'єднання народностей, вважалося «завершенням справи великого князя Івана Калити», тобто об'єднання руських народностей в їх етнографічних межах» (Мілюков, 1915:18-27).

3 другого боку, захопивши західноукраїнські землі, царський уряд прагнув назавжди покінчити 3 «мазепинством», вирішити українське питання в столипінському дусі, тобто заборонити всі «інородницькі» громадські та культурницькі організації «безвідносно до тих цілей, які вони перед собою ставлять»; проводити правове обмеження релігійних структур, які не входили до складу панівної Російської православної церкви, обмежити права і свободи за національною та конфесійною ознакою, здійснювати державний антисемітизм (смуга осілості), відсоткову норму, не кажучи вже про толерантне ставлення влади до єврейських погромів, заборону публічно використовувати українську мову, русифікація і, таким чином, побороти будь-що український сепаратистський рух (Дергачов, 1996:434). 
Зрозуміло, що напередодні війни українське питання стало надзвичайно важливим не тільки для царського уряду, але й для російського загалу. Для них тепер небайдужим було майбутнє українського народу, як відбуватиметься подальший його розвиток, чи він здобуде незалежність, чи зіллється з російським. «Тут «зарита собака» всієї антиукраїнської політики царизму і великоруського суспільства, - зазначав австрійський соціал-демократ О. Бауер, звідси також одностайність (з незначними виключеннями) у поглядах на воєнні цілі стосовно австрійської України. Більмом в очах Росії вона стала з того моменту, коли завирувало тут животворне джерело української національної ідеї, коли іскри національної свідомості стали перекидатися через російський кордон, за Збруч, в міста і села російської України» (Левинський, 1917:104).

Для захисту своїх територій (Правобережної України та Західної Волині), які відносно недовго перебували у складі Росії, владі необхідно було забезпечити інформаційний захист прикордонних губерній. Побоюючись, що «існування малоросійської гілки в Австрії приведе до відродження українського питання» (Бережинський, 2001:89), уряд посилив протидію українському національно-визвольному рухові, який звинувачував у сепаратизмі, тобто спробам ослабити чи відірвати малоросів від великоросів. Причому розрізнявся сепаратизм політичний (I. Мазепа, I. Виговський) i культурно-етнографічний чи українофільський (М. Костомаров, П. Куліш) (Щёголев, 1912: 588).

Уже в січні 1914 р. Клуб російських націоналістів у Києві застерігав уряд щодо посилення української пропаганди в Російській імперії. На їхню думку, метою цієї пропаганди було доведення окремішності малоросійського народу та його права на національно-політичну та культурну самостійність, а згодом i відторгнення Малоросії (за сприянням Галичини) і включення іii до складу Австро-Угорщини на федеративних засадах як автономної одиниці (Щёголев, 1912:588).

Відкидаючи такі звинувачення, українська інтелігенція переконувала російську громадськість, що не прагне відокремлення від Росії, якщо українському народу буде надана широка національно-культурна автономія (Украинский вопрос, 1914:134).

«Тому й кинулася Росія відразу на Галичину, - підкреслював німецький вчений Аксель Шмідт у статті «Кінцева ціль Росії», щоб, здобувши український П'ємонт, задушити в зародку українське відродження» (Кінцева иџіль Росії, 1916:537-538). 
Українські землі мали для двох воєнно-політичних блоків не тільки геополітичне, але й економічне значення. Західно-українські землі, які знаходилися в центрі Свропи, завжди приваблювали іноземців. У 1914 р. майже третя четвертина загального видобутку нафти у Дрогобицько-Бориславському басейні зосереджувалася в руках німецьких монополій: "Petroleumaktiengeselschoft", "Galizische Karpaten", "Deutsche Erdöl” та ін. (Кулінич, 1963:216)

Результатами москвофільської пропаганди в Галичині перед війною та на іiі початку стало упереджене ставлення австроугорського військового командування до українського населення краю, яке підозрювали у шпигунстві, допомозі російським розвідникам, загалом у нелояльності австрійській владі, що призводило до репресій (Ронге, 1939:244).

3 вибухом війни Російська та Австро-Угорська імперії розпочали широку кампанію мобілізаційних заходів. Росія ще 29 липня 1914 р. провела мобілізацію у прикордонних з Австро-Угорщиною військових округах, а 30 липня оголосила загальну мобілізацію. Внаслідок цього до російського війська призвано близько 70 тис. чоловіків Західної Волині: українців, росіян, поляків, чехів (Берест, 2009:20).

Військові дії держав вимагали значної підтримки населення і iï прагнули забезпечити за допомогою пропаганди, що розпочалася задовго до початку війни і була обумовлена зовнішньополітичною ситуацією. 5 серпня та 17 вересня 1914 р. були видані відозви до російського народу і до народів Австро-Угорщини. В них наголошувалося, що спадщина Київської Русі у вигляді західноукраїнських земель повинна була відійти до єдиної нероздільної Росії (Год войны, 1915:588). Відозва до населення Галичини закликала мобілізованих українців-військово-службовців австроугорської армії здаватися в полон, нагадуючи про їх релігійну та етнічну спорідненість з наддніпрянцями (ЦДІАУК, ф. 442, on. 864, спр. 279, арк. 1).

3 початком бойових дій на галицьких землях вже 11 серпня 1914 р. за підтримкою російських урядових кіл у Києві був заснований «Карпато-Русский Освободительный комитет», головою якого обрано літературознавця Ю. Яворського, секретарем - редактора «Прикарпатской Руси» С. Лубенського, а членами - діячів «Народного Совета Галицкой Руси» М. Глушкевича, Ю. Сьокала, М. Сохоцького. Комітет мав наступні завдання: 1) оповіщати російську суспільність і визвольну російську армію про історичні переживання та 
теперішне політичне становище «російського Прикарпаття»; 2) опікуватися воєнними втікачами і полоненими «російськими галичанами» (Петрович, 1915:116). Для виконання цих завдань головну роль мав відігравати періодичний орган - «Прикарпатская Русь», видання різноманітних летючок, а також влаштування публічних зборів і виступів (Семенів, 2018:526).

Того ж дня комітет видав декількатисячним накладом відозву «Многостраждальный Русский Народ Галицкой Руси» для поширення серед цивільного населення і військових. Відозва закликала галичан вітати російську армію, а українських вояків австроугорської армії - переходити на сторону російського війська (Современная Галичина, 1914:31). Після зайняття Львова російськими військами Комітет передав свої повноваження «Русскому Народному Совету» на чолі з В. Дудикевичем.

За допомогою комітету при військово-цензурному відділенні штабу головнокомандувача арміями Південно-Західного фронту була підготовлена брошура «Современная Галичина». У ній подано відомості про етнографічне, культурне становище краю, політичні партії та політичних лідерів, їх ставлення до Росії. Український рух представлено як інтригу інтелігенції, яка не відігравала особливої політичної ролі, його названо штучним, який можна легко подолати.

У брошурі окремо виділено ставлення до українофілів. Зокрема зазначалося, що до селян 3 українського табору, поки вони активно не виступатимуть проти нової влади, потрібно ставитися прихильно, адже вони, обмануті інтелігенцією, не можуть зорієнтуватися у певних обставинах, бо не знають «великоруської і малоруської історичної та побутової правди». Щодо інтелігенції, то слід зайняти очікувальну позицію і діяти в залежності від іiї поведінки та усвідомлення реального становища, що дасть можливість «забути давнє і нам не прийдеться застосовувати суворих законів воєнного часу» (Современная Галичина, 1914:31).

Вказана брошура призначалася для ознайомлення офіцерів російської армії з політичною ситуацією в Галичині. Слід зазначити, що «Современная Галичина», по суті, розкривала все москвофільство, називаючи всіх членів москвофільських організацій, на підтримку яких могли розраховувати росіяни. На основі тієї брошури австро-угорська контррозвідка виготовила карту Галичини і Буковини, на якій окремо зазначено всі місцевості, де жили 
найвизначніші москвофільські діячі та їх прізвища, а також подано назви всіх найважливіших довоєнних москвофільських часописів Галичини і Буковини (Андрусяк, 1935:78). Брошура, потрапивши до рук австрійської розвідки, дала підставу австрійським властям провести у краю низку арештів українців різних політичних напрямів (Макарчук, 2001:236).

Австрійське військове керівництво та Галицьке намісництво 15 серпня 1914 р. видали у Львові розпорядження про боротьбу 3 москвофільським рухом із застосуванням засобів екзекуції та помилування. Цивільна та військова влада здійснювала i превентивні арешти політично неблагонадійних представників з різних прошарків галицького суспільства. Вже 20 серпня 1914 р. у Львові заарештовано 1200 осіб, а 4 вересня 1914 р. до Талєргофа привезли 1600 мешканців Львова і 700 осіб зі станіславської тюрми. Зазначимо, що тільки в Талєргофі більшість інтернованих складали українці - близько 7 тисяч зі Східної Галичини і понад тисячу осіб інших регіонів (Освободительная война, 1914:2-3).

Українофільство стало домінантною течією громадського життя галицьких українців, а Східна Галичина перетворилася на «Український П'ємонт» і стала важливим чинником формування модерної української ідентичності, що поступово завойовувала обидва береги Збруча (Верстюк, 204:66-72).

Урядові чиновники Австро-Угорщини, оцінюючи тогочасну ситуацію в Південно-західній частині Російської імперії, прагнули за допомогою галицьких українців «схилити рутенів (наддніпрянських українців) до «австрійської ідеї». Австрійські політики вважали, що в Наддніпрянщині «утворилася група прихильників так званої «австрійської орієнтації» на чолі з Кониським» (Кураєв, 2008:311). Окремі 3 них сподівалися у перспективі приєднати частину Наддніпрянської України до Габсбурзької монархії. Вона, зокрема, претендувала на Волинь і Поділля, водночас не відмовляючись від панування в Східній Галичині, Закарпатті та Північній Буковині (Андрусишин, 1998:17-23).

Висновки. Російська імперія намагалася інформаційно-психологічно підготувати населення західноукраїнських земель до майбутнього театру бойових дій. Державна пропагандистська машина працювала над організацією інформаційної дискредитації ворога та створенням позитивного іміджу власної держави та армії. 
Слід зауважити, що ідеологічно-пропагандистська війна розпочалася задовго до військових дій Росії на Південно-Західному фронті та супроводжувалася на всіх етапах війни, завчасно адаптуючись під поточні цілі та задачі. Пропагандистські заходи були спрямовані на всі верстви населення Австро-Угорщини, а також на українське населення Російської імперії.

Головною метою ідеологічної політики було отримання підтримки населення для виправдання військових дій царської Росії, ліквідація українського національно-визвольного руху.

Аналіз досліджень даної проблематики у вітчизняній історичній науці свідчить про те, що низка питань залишається відкритими донині та потребує подальшого вивчення і доопрацювання. Перспективним напрямом історичного дослідження є вивчення питання, як рівень освіченості населення та військових впливав на сприйняття та засвоєння ними повідомлень власної та ворожої пропаганди.

\section{Використані посилання}

Bihl W. 1990. Die Beziehungen zwischen Osterreich-Ungaru und Russland in bezug auf die galizische Frage 1908-1914. Calizienum die lahrhunderts wende. Wien; Munchen, s. 41.

Hornykiewicz T. 1966. Ereignisse in der Ukraine 1914-1922 deren Bedeutung und historische Hintergrunde. Philadelphia, s.56-71.

Wasilewski L. 1934. Kwestja ukrainska jako zagadnienie miedzynarodowe. Prace Ukrainskiego Instytutu Naukowego. Warszawa. T. 28, z. 1, s. 98

Андрусишин Б. 1998. Україна в роки Першої світової війни. Перша світова війна і слов'янські народи: матеріали міжнародної наукової конференції. Київ, c. 18.

Андрусяк М. 1935. Нариси з історії галицького москвофільства 3 портретами москвофільських діячів. Львів: Просвіта, с. 52.

Бахтурина А. 2000. Политика Российской империи в Восточной Галиции в годы Первой мировой войны. Москва: АИРО-ХХ, с. 41-42.

Берест I. Соціальне становище населення Східної Галичини і Західної Волині в роки Першої світової війни (автореф. дис. на здобуття наук. ступ. канд. істор. наук: спец. 07.00.01 - Історія України) Львів, с. 6.

Верстюк В. 2004. Україна-Росія: виборювання ідентичності. Актуальні проблеми вітчизняної історії ХХ ст. Київ. Т.1, с. 68.

Год войны с 19 июля 1914 г. по 19 июля 1915 г. Высочайшие манифесты и воззвание Верховного главнокомандующего. 1915. Петроград, с. 11.

Гумецкий И. 1904. Значения Прикарпатья для России: Прикарпатье, будущее-второе Приамурье для России, в предстоящей ей борьбе с вероломною Западною Европою. Санкт-Петербург: Тип. В. Комарова, с. 33.

Дело народных читален. 2014. Прикарпатская Русь. Львов. 20 октября, с.1.

Дергачов О. 1996. Украӥнська державність у ХХ столітті. Київ: Політична думка, с. 275. 
Кінцева ціль Росії. 1916. Вістник Союза визволення України. Відень. Ч. 52. c.537-538.

Кулінич I. 1963. Украӥна в загарбницьких планах німещъького імперіалізму (1900-1914 рр.). Київ, с. 36-37.

Кураєв О. 2008. Українська проблема в політиці Берліна та Відня у Першій світовій війні (1914-1918). Київ: НАН України; Інститут української археографії та джерелознавства ім. М.С. Грушевського, с. 14.

Куцька О. М. 2014. Воєнна пропаганда періоду Першої світової війни / О. М. Куцька. Периа світова війна у військово-історичному вимірі (до 100-річчя nодіï): Збірка матеріалів Міжнародного наукового форуму. Львів: АСВ, c. $188-191$.

Левинський В. 1917. Царская Россия и украинский вопрос. Женева: Изд. Укр. с. д. раб. Канады, с. 198.

Левицький К. 1926. Історія політичної думки галицьких украйнців (1848-1914). На підставі споминів і документів. Львів, с. 701.

Макарчук С. 2001. Москвофільство: документи і матеріали. Львів: ЛНУ ім. І. Франка, с. 61.

Милюков П. 1915. Территориальные приобретения России. Чего ждет Россия от войны. Сб. статей. Санкт-Петербург, с. 20.

Мосієнко О. В. 2017. Аналіз результативності австро-угорської та російської пропаганди на Південно-Західному фронті Першої світової війни. Науково-теоретичний альманах «Грані». Дніпро, №11, с. 30-35.

Науменко А. О. 2013. Бойова діяльність військ 11-ї армії у травні-вересні 1916 року. Воєнно-історичний вісник. №2, с. 46-55.

Освободительная война. 1914. Прикарпатская Русь. Львов. 6 октября, с.2-3.

Пасічник В. М. 2014. Російська імперська суспільна система: сутність, ознаки та етапи розвитку (злам XIX - XX ст.). Перша світова війна у військовоісторичному вимірі (до 100-річчя подіï): Збірка матеріалів Міжнародного наукового форуму Львів: АСВ, с. 89-91.

Петрович I. 1915. Галичина під час російської окупації: серпень 1914 червень 1915. Відень: Політична бібліотека. с. 7.

Ронге М. 1939. Разведка и контрразведка. Москва: Воениздат НКО СССР, с.106

Семенів В. (упор.). 2018. Московська окупачія Галичини 1914-1917 рр. $в$ свідченнях сучасників. Львів: Апріорі, с. 26.

Современная Галичина. Этнографическое и культурно-политическое состояние ее в связи с национально-общественными настроениями. Записка составленная при Военно-цензурном отделении Управления генералквартирмейстера Штаба главнокомандующего армиями Юго-Западного фронта (Июль 1914 г.). Б. м. 31 с. 10,12.

Струве П. 1914. Великая Россия и Святая Русь. Москва: Русская мысль. Кн. XII, с. 178.

Томашівський С. 1915. Галичина. Політико-історичний нарис з приводу війни. Львів. с. 18-32.

Украинский вопрос. 1914. Издание редакции журнала «Украинская жизнь». Санкт-Петербург: Электро-типография Н. Я. Стойковой, с. 91-92.

Уська У. 2004. Політика офіційного Відня та Галицького намісництва щодо русофільського руху в 1908-1914 pр.. Історичні та культурологічні студіі. Львів: Ін-т українознавства НАН України, Вип. 3, с. 179. 
Центральний державний історичний архів Украӥни, м. Київ (ЦДІАУК), ф. 442, оп. 864, спр. 279, 15 арк.

Щёголев С. Н. Украинское движение как современный этап южнорусского сепаратизма. Киев: Типография И. Н. Кушнерев и Ко, 1912, с. 3,5.

\section{References}

Bihl W. 1990. Relations between Austria-Hungary and Russia in relation to the Galician Question 1908-1914. Calizienum the turn of the century. Vienna; Munchen, p.41(ger).

Hornykiewicz T. 1966. Events in Ukraine 1914-1922 their meaning and historical background. Philadelphia, p.56-71(ger).

Wasilewski L. 1934. Ukrainian question as an international issue. Works of the Ukrainian Scientific Institute. Warsaw. Vol. 28, z. 1, p. 98 (pl).

Andrusyshyn B. 1998. Ukraine during the First World War. The First World War and the Slavic peoples: materials of the international scientific conference. Kiev, p.18 (ukr).

Andrusiak M. 1935. Essays on the History of Galician Muscophilia with Portraits of Muscophilian figures. Lviv: Prosvita, p. 52 (ukr).

Bahturina A. 2000. The policy of the Russian Empire in Eastern Galicia during the First World War. Moskow: AIRO-XX, p. 41-42 (rus).

Berest I. 2009. The social situation of the population of Eastern Galicia and Western Volyn during the First World War (dissertation author's abstract on obtaining a scientific degree of candidate of historical sciences: spec. 07.00.01 - History of Ukraine) Lviv, p. 6 (ukr).

Verstiuk V. 2004. Ukraine-Russia: the choice of identity. Actual problems of the national history of the XX century. Kyiv. Vol. 1, p. 68 (ukr).

The year of the war from July 19, 1914 to July 19, 1915. The highest manifestos and the appeal of the Supreme Commander. 1915. Petrograd, p. 11 (rus).

Gumetskiy I. 1904. The values of the Carpathian region for Russia: the Carpathian region, in the future the second Amur region for Russia, in its forthcoming struggle against the treacherous Western Europe. St. Petersburg: Printing House V. Komarova, p. 33 (rus).

The case of folk read. 2014. Carpathian Rus. Lviv. October 20, p.1 (rus).

Derhachov O. 1996. Ukrainian statehood in the twentieth century. Kyiv: Politychna dumka, p.434 (ukr).

Russia's ultimate goal. 1916. Bulletin of the Union of Liberation of Ukraine. Vienna. Part 52, pp. 537-538 (ukr).

Kulinych I. 1963. Ukraine in the invasion plans of German imperialism (19001914). Kyiv, p.36-37(ukr).

Kuraiev O. 2008. The Ukrainian Problem in the Politics of Berlin and Vienna in the First World War (1914-1918). Kyiv: NAS of Ukraine; Institute of Ukrainian Archeography and Source Studies M.S. Hrushevsky, p. 14 (ukr).

Kutska O. 2014. Military propaganda of the First World War/O.M. Kutska. World War I in military-historical dimension (to the 100th Anniversary of the event): Proceedings of the International Scientific Forum. Lviv: ASV, p. 188-191 (ukr).

Levynskyi V. 1917. Tsarist Russia and the Ukrainian Question. Geneva: ed. ukr. d. s. rab. Canada, p. 98 (rus).

Levytskyi K. 1926 History of political thought of Galician Ukrainians (1848 1914). Based on memories and documents. Lviv, p. 701(ukr). 
Makarchuk S. 2001. Muscophilia: documents and materials. Lviv: LNU I. Franko, p. 61(ukr).

Milyukov P. 1915. Territorial acquisitions of Russia. What does Russia expect from the war? Digest of articles. St. Petersburg, p. 20 (rus).

Mosiyenko O. V. 2017. An Analysis of the Effectiveness of Austro-Hungarian and Russian Propaganda on the Southwestern Front of World War I. Scientifictheoretical almanac "Grani". Dnipro, No. 11, pp. 30-35 (rus).

Naumenko A. O. 2013. The combat activities of the troops of the 11th Army in May-September 1916. Military Historical Bulletin. №2, p. 46-55 (ukr).

War of liberation. 1914. Carpathian Russia. Lviv, October 6, p. 2-3 (rus).

Pasichnyk V. M. 2014. The Russian imperial social system: the essence, features and stages of development (the collapse of the nineteenth - twentieth centuries.). The First World War in military-historical dimension (to the 100th Anniversary of the Event): Collection of Materials of the International Scientific Forum Lviv: ASV, p.89-91 (ukr).

Petrovych I. 1915. Galicia during the Russian occupation: August 1914 - June 1915. Vienna: Political Library. p.7 (ukr).

Ronge M. 1939. Intelligence and counterintelligence. Moscow: Military Publishing House of the NKO of the USSR, p.106 (rus).

Semeniv V. (compiler). 2018. Moscow occupation of Galicia 19141917 in the testimony of contemporaries. Lviv: Apriori, p.26 (ukr).

Modern Galicia. Ethnographic and cultural-political state of it in connection with national-public moods. A note drawn up at the Military Censorship Division of the Office of the Quartermaster General of the Head of the Armies of the South-Western Front (July 1914). B.M. 31, p.10,12 (rus).

Struve P. 1914. Great Russia and Holy Russia. Moscow: Russkaya mysl. Book XII, p.178 (rus).

Tomashivskyi S. 1915. Galicia. Political and historical essay on the war. Lviv. 18-32 (ukr).

Ukrainian question. 1914. Edition of the editorial office of the journal "Ukrainian Life". St. Petersburg: Electro-printing house N. Ya. Stoykova, p. 91-92 (rus).

Uska U. 2004. Policy of official Vienna and Galician governorate of the Russophile movement in 1908-1914. History and cultural studies. Lviv: Institute of Ukrainian Studies, NAS of Ukraine, Iss. 3, p.179 (ukr).

Central State Historical Archives of Ukraine, Kyiv (CSIAUK), f.442, op.864, case 279,15 sheets (ukr).

Shchegolev S. N. The Ukrainian movement as a modern stage of South Russian separatism. Kiev: Printing house I. N. Kushneryov and Co., 1912, p.3.5 (rus).

\section{Vyzdryk V.}

THE IDEOLOGICAL INFLUENCE OF RUSSIA ON THE UKRAINIAN GALICIA SOCIETY ON THE EVE AND INITIAL STAGE OF THE FIRST WORLD WAR

The beginning of the twentieth century marked the use of ideology as a tool of foreign policy. Thus, Russia entered the First World War under the slogan of the liberation of the enslaved Slavs. At the same time, the Russian government sought to implement its pre-war strategic goal, to expand the borders of the empire at the expense of Galicia, Bukovina and Transcarpathia. 
On the eve of the war the instrument of information policy of the Russian Empire was Pan-Slavism, a messianic mission for the Slavic peoples. The ideology of PanSlavism envisaged the expansion of the Russian Empire at the expense of Red Russia. For expansion, Russia used cultural and religious influence and, through it, its political presence in the region.

In order to discredit the Ukrainian national-liberation movement in Galicia, on the eve of the war, Russian governmental and political circles supported, morally and, above all, materially, the Muscophilia, which underpinned the all-Russian national idea. Through Muscophilian organizations, the Russian government was able to carry out not only anti-Ukrainian propaganda among Galician Ukrainians, pulling them to their side, but also anti-state, in order to accidence to Russia all Ukrainian ethnographic lands that were part of the Austro-Hungarian monarchy.

On August 11, the Carpatho-Russian Liberation Committee was set up in Kyiv. Its task was to: clarify the so-called "reunification", introduce the Russian administration, and treat the Russian army to the local population; as well as assistance to the refugees and captive Galicians of the Austro-Hungarian army. In addition, in July 1914, Muscophiles issued for the command staff a small work "Modern Galicia", which emphasized the importance of Russophilism in Galicia, the place of residence of the names of members of the Russian People's Council, while neglecting Ukrainian political and national-cultural movement.

Thus, the Russian Empire tried to information-psychological approach the population to the future theater of combat. The state propaganda machine work on the organization of the information discredit of the enemy and creation a positive image of his own state and army.

It should be noted that the information war began long before Russia's hostilities and was accompanied at all stages of the war, adapting in advance to current goals and objectives;

outreach activities directed to all layers of the populations of Austria-Hungary, as well as the Ukrainian population of the Russian Empire, respectively, with different goals and objectives;

the main purpose of the information war is to obtain the support of the population to justify the actions of the military leadership of the warring parties; the liquidation of the Ukrainian national liberation movement.

Keywords: First World War, Galicia, Muscophilia, information influence, propaganda. 